\section{Effects of light intensity and the remaining nitrate concentration on the beta-carotene accumulation of a wild Dunaliella salina strain isolated from the saline soil}

\author{
Zhe Wu, ${ }^{1,2}$ Rokeya Akter, ${ }^{1}$ \\ Wallop Arirob, ${ }^{1}$ Niran Juntawong, ${ }^{1}$ \\ Chunhong Ma, ${ }^{2}$ Promchup Duangmanee ${ }^{1}$ \\ ${ }^{1}$ Faculty of Science, Kasetsart University, \\ Thailand; ' Institute of Genetics and \\ Physiology, Hebei Academy of \\ Agriculture and Forestry Sciences, Plant \\ Genetic Engineering Center of Hebei \\ Province, China
}

\section{Abstract}

An isolated Dunaliella salina strain from northern Thailand was cultured in modified Johnson's medium in column photobioreactor. The beta-carotene accumulation mainly depended on the quantities of cells entering into carotenogenesis condition that was significantly enhanced by high started $\mathrm{KNO}_{3}$ concentration. Low remaining nitrate concentration in the culture of each cell (RNCC) was suitable for algae to accumulate beta-carotene. Following the cultivation time extended, RNCC of all cultures decreased and tended to the same level (10-20 pg/cell) although the biomass or betacarotene content in the culture was higher in high started $\mathrm{KNO}_{3}$ concentration. High light intensity restrained the growth especially in low $\mathrm{KNO}_{3}$ concentration but improved betacarotene accumulation and RNCC. The highest biomass and beta-carotene dry weight (DW) were $2.25 \mathrm{~g} \mathrm{~L}^{-1}$ and $79.2 \mathrm{mg} \mathrm{g}^{-1} \mathrm{DW}$ respectively. Above results indicated that increasing the biomass and as early as possible to strengthen the stress on each cell was important to improve the final beta-carotene yield.

\section{Introduction}

Beta-carotene is a carotenoid, one of groups of plant pigments known to have antioxidant and other effects. This is a substance in plants that's quickly converted into vitamin A inside the body. Beta-carotene is often thought of as a form of vitamin A itself. Having normal levels of vitamin A is important for good vision, strong immunity, and general health. ${ }^{1-3}$ The most important natural beta-carotene resource come from the cultivation of the unicellular biflagellate marine green microalga Dunaliella spp. ${ }^{4}$ Dunaliella salina (D.salina) is an ideal species in algal production because of its extremely adaptability to various adversity stress. ${ }^{5,6}$

Present studies have confirmed that betacarotene yields can be improved under stress conditions such as high irradiance, high temperatures, high salt concentration and/or nutrient deficiency etc. ${ }^{4,7}$ However, one of problems was that increasing stresses could decrease the biomass although the betacarotene content per cell is significantly improved. $4,6,8$ Therefore, the main optimization or research targets of beta-carotene production are finding a balance between the maximum biomass and beta-carotene yield. ${ }^{7-9}$ $\mathrm{KNO}_{3}$ is one of the main factors to directly affect the biomass and beta-carotene accumulation. Low nitrate concentration is suitable for beta-carotene production but opposite for biomass accumulation. However, the living habits of each algae species or strain are different that resulted the biomass or beta-carotene yields is different under the same $\mathrm{KNO}_{3}$ concentration.

In order to obtain the maximum betacarotene yield, developing the photo-bioreactors or two-phase cultivation were often mentioned and developed in algal production. ${ }^{2,10}$ These methods mainly focused on the improvement of stress conditions, e.g. modifying the nutrition concentration or components of culture medium, increasing the illuminated surface, adjusting temperature, salinity or $\mathrm{pH}$ etc. These methods provided a lot useful proposes in algal production. However, conclusions of these methods were not very in agreement, e.g. some studies pointed that $10 \mathrm{mM}, 5$ $\mathrm{mM}$ or $2 \mathrm{mM}$ even $1 \mathrm{mM}$ nitrate were suitable for algae growth.,7,11-13 Hence, the relations among the remaining nitrate concentration in the culture medium, cell quantities and betacarotene accumulation were studied to explain these differences in this research.

Moreover, D.salina strain KU XI in this research was isolated from saline soil in Chaiyaphum, Thailand, where $\sim 17 \%$ area was covered by saline-alkali soil and suitable for commercial algal production. ${ }^{9}$ Hence, aims of this research were also to study the growth, beta-carotene accumulation and cell morphology of this isolated wild strain under different way of adding $\mathrm{KNO}_{3}$ with the hypothesis that improving the stress on each cell could enhance the total beta-carotene yields. Meanwhile, results of this study could also be used for future commercial algal production in northern Thailand.

\section{Materials and Methods}

[Microbiology Research 2015; 6:6233]
Correspondence: Promchup Duangmanee, Faculty of Science, Kasetsart University, Bangkok 10900, Thailand.

Tel.: +669215.28148 - Fax: +66.2940 .5627 .

E-mail: sucinsist@gmail.com

Key words: Biomass; beta-carotene; Dunaliella salina; light stress; nitrate limitation.

Acknowledgements: authors would like to thank the Faculty of Science, Kasetsart University and the Institute of Genetics and Physiology, Hebei Academy of Agriculture and Forestry Sciences for providing the strains and experimental instruments.

Contributions: $\mathrm{ZW}$ developed the original idea and the protocol, abstracted and analyzed data, wrote the manuscript; CM provided the methods and instruments; $\mathrm{NJ}$ and PD provided the idea, experimental materials, equipment, manuscript correction and finical support; RA and WA attended the experiment and reviewed the manuscript.

Conflict of interest: the authors declare no potential conflict of interest.

Funding: the work was supported by the Bioscience program, Science of faculty, Kasetsart University, Thailand.

Received for publication: 5 October 2015 . Accepted for publication: 5 October 2015.

This work is licensed under a Creative Commons Attribution NonCommercial 3.0 License (CC BYNC 3.0).

(C) Copyright Z. Wu et al., 2015

Licensee PAGEPress, Italy

Microbiology Research 2015; 6:6233

doi:10.4081/mr.2015.6233

D. salina strain KU XI was obtained from bioscience lab of Faculty of Science, Kasetsart University, Thailand and cultured in modified Johnson's medium in column photobioreactor at 30 with a working volume of $250 \mathrm{~mL}^{9}$. The salinity ( $\mathrm{NaCl}$ concentration) was $2.5 \mathrm{M}$. Initial $\mathrm{pH}$ and cell density was controlled at 7.5 and approx. $70 \times 10^{4} \mathrm{~mL}^{-1}$. Bioreactors were aerated with compressed air containing $5 \% \mathrm{CO}_{2}(\mathrm{v} / \mathrm{v})$ at approx. $0.01 \mathrm{vvm}$ (volume of air per volume of medium per minute) and irradiated continuously from two sides with cool white fluorescence lamps giving $54 \mu \mathrm{mol} \mathrm{m} \mathrm{m}^{-2} \mathrm{~s}^{-1}$ and 200 $\mu \mathrm{mol} \mathrm{m}{ }^{-2} \mathrm{~s}^{-1}$ respectively ${ }^{14}$.

$\mathrm{KNO}_{3}$ concentration was set at $0.1,0.2,0.3$ $0.5,0.75$ and $1 \mathrm{~g} \mathrm{l}^{-1}$ respectively as 6 treatments with 4 repetitions of each. Two groups were designed, namely non-fixed and fixed $\mathrm{KNO}_{3}$. In the first group, different $\mathrm{KNO}_{3}$ concentrations were one-time added at the first day and the started cell density was approx. $70 \times 10^{4} \mathrm{~mL}^{-1}$; In 
the second group, algae were preliminarily cultured in the modified Johnson's medium with $1.5 \mathrm{M} \mathrm{NaCl}$ and $1 \mathrm{~g} \mathrm{KNO}_{3} \mathrm{I}^{-1}$ for 7 days and the biomass was collected by centrifugation ( 4000 rpm, $5 \mathrm{~min}$ ). The biomass was uniformly added into each treatment and finally the started cultivation cell density was approx. $8 \times 10^{6} \mathrm{~mL}^{-1}$. $\mathrm{KNO}_{3}$ was multiple supplemented to the medium every two days for maintaining the same nitrate concentration as the first day.

Modified alkaline potassium persulfate digestion-UV spectrophotometric method (Chinese national standard, GB 11894-89) was used to check nitrate concentration. $10 \mathrm{ml}$ algae solution was diluted 20 times or higher then filtered $(0.45 \mu \mathrm{m}) .1 \mathrm{~mL} \mathrm{HCl}$ was added into $10 \mathrm{ml}$ filtered solution and then fixed this sample to $50 \mathrm{ml}$ with deionized water. The optical density (OD) of this diluted sample was checked by HP8453 ultraviolet spectrophotometer manufactured by Hewlett-Packard Company (Paolo Alto, CA, USA) and calculated the $\mathrm{OD}$ value difference $\left(\mathrm{OD}_{220}-2 \times \mathrm{OD}_{275}\right)$. Nitrate concentration could be directly calculated by the standard nitrate curve which was determined by a series of known $\mathrm{KNO}_{3}$ concentration and their $\mathrm{OD}$ value difference $\left(\mathrm{OD}_{220}-2\right.$ $\times\left(\mathrm{OD}_{275}\right)$. Finally, the remaining nitrate concentration in the culture of each cell (RNCC) was calculated:

RNCC $=C_{n} / N \times 10^{6}$, where the $C_{n}$ was concentration of nitrate in the culture $\left(\mu \mathrm{g} \mathrm{mL}^{-1}\right)$ and $\mathrm{N}$ was cell density (cells $\mathrm{mL}^{-1}$ ), the unit of RNCC was pg/cell.

The biomass was harvested after 15 days by centrifugation and dried in oven at $60^{\circ} \mathrm{C}$ for three days. Cell densities was checked by daily counting in a hematocytometer and the raw data was processed with the method of sigmoid curve fitting by the software of Table Curve 2D v5.01 for calculating relative growth rate (RGR) and specific growth rate $(\mu)$ :

$\mathrm{RGR}=\ln \left(\mathrm{N}_{2} / \mathrm{N}_{1}\right) /\left(\mathrm{t}_{2}-\mathrm{t}_{1}\right)$;

$\mu=\ln 2 / t_{D}$, where $N_{2}$ or $N_{1}$ was the cell density at the check day and the first day; $t_{2}, t_{1}$ and $t_{D}$ was the check day, first day and doubling time respectively. Beta-carotene was extracted by 95\% acetone and its extraction solution was analyzed and checked by Waters e2695 HPLC with Waters RP18 Column $5 \mu \mathrm{m}$, manufactured by Waters Company, Milford, USA. In the mobile phase, solvent A was ethyl acetate and solvent B was acetonitrile and water $(9: 1, \mathrm{v} / \mathrm{v})$. The flow rate was $1 \mathrm{~mL} \mathrm{~min}{ }^{-1}$. The solvent programming was that: $0-16$ min, $0-60 \%$ solvent $A$; $16-30$ min, $60 \%$ solvent A; $30-35$ min, $100 \%$ solvent A. ${ }^{2,15}$ Finally, beta-carotene content was converted by dry biomass weight ( $\left.\mathrm{mg} \mathrm{g}^{-1} \mathrm{DW}\right)$. All the data analysis was processed by the software of Microsoft Excel 2010 and SPSS 16.0 with the method of ANOVA and t-Test.

\section{Results and Discussion}

\section{Biomass and beta-carotene content under different light intensity and $\mathrm{KNO}_{3}$ concentration}

Increasing $\mathrm{KNO}_{3}$ concentration could significantly improve the beta-carotene content and the growth under different light intensity, however, their specific growth rate did not show a corresponding tendency (Table 1 and Figure 1). High light intensity was suitable for betacarotene accumulation but opposite for biomass accumulation. The beta-carotene content $\left(\mathrm{mg} \mathrm{L}^{-1}\right)$ in high light intensity was not significant higher than in low light intensity $(\mathrm{t}=1.81, \mathrm{P}=0.45)$. Moreover, the beta-carotene contents (pg/cell, mg L-1) in high $\mathrm{KNO}_{3}$ concentration were both higher than in low $\mathrm{KNO}_{3}$ concentration (Table 1 and Figure 1), however, the beta-carotene content ( $\mathrm{mg} \mathrm{L}^{-1}$ ) under the low and high light intensity was not significant difference when $\mathrm{KNO}_{3}$ concentration higher than $0.75 \mathrm{~g} \mathrm{~L}^{-1}(\mathrm{~F}=5.98, \mathrm{P}=0.19$ and $\mathrm{F}=5.98$, $\mathrm{P}=0.16$ respectively). This result could be related with the stress of nitrate limitation on each cell or required more time to accumulate beta-carotene. Above results showed that the final biomass or beta-carotene content was mainly affected by the started nitrate concentration.

Previous studies mentioned that $10 \mathrm{mM}, 5$ $\mathrm{mM}, 2 \mathrm{mM}$ and $1 \mathrm{mM}$ nitrate were suitable for algae growth. ${ }^{4,7,11-13}$ Prevalent views that high nutrition or low stress intensity was suitable for growth and opposite for beta-carotene accumulation. ${ }^{12,16,17}$ However, results of this study were not very consistent with these results and showed that the beta-carotene contents (pg/cell, mg $\mathrm{L}^{-1}$ ) were both improved when increasing the $\mathrm{KNO}_{3}$ from $0.1 \mathrm{~g} \mathrm{~L}^{-1}$ to $0.75 \mathrm{~g} \mathrm{~L}^{-1}$ (Table 1). Results of this study also showed that growth of this D.salina strain was enhanced when $\mathrm{KNO}_{3}$ greater than $0.4 \mathrm{~g} \mathrm{~L}^{-1}$. Obviously, here arises a question that what concentration of nitrate was suitable for growth or beta-carotene accumulation? The nutrition in medium would be rapidly consumed when the algae reproduced massively. Above mentioned nitrate concentrations were all the started nitrate concentration. Also, growth and nutrition consumption in different environment or algae species were different. Hence, especially in the late cultivation stage, the remaining nutrition would be more effective on the growth or beta-carotene accumulation.

Nitrogen resource was a vital factor for $D$. salina growth or beta-carotene production. Algae would die if absent nitrogen resource long time. ${ }^{8,18}$ Only the living cells under the long period of nitrate limitation could synthesis large amount of carotenoids for maintain- ing the photosynthesis and metabolism. ${ }^{19}$ Therefore, some algae cells in the low started nitrate concentration could not exist long enough to accumulate beta-carotene in the late stage and died or the new reproductive cells not yet to produce beta-carotene. Hence, the beta-carotene contents (pg/cell, $\mathrm{mg} \mathrm{L}^{-1}$ ) in the culture of low started nitrate concentration were lower than in high started $\mathrm{KNO}_{3}$ concentration. Moreover, it also indicated that quantities of living cells especially those cells entered into carotenogenesis conditions in the late stage would be vital for final beta-carotene yield.

\section{Biomass and beta-carotene content under different light intensity and fixed concentration of $\mathrm{KNO}_{3}$}

Low $\mathrm{KNO}_{3}$ concentration significantly limited the growth and beta-carotene accumulation (Figure 2 and Table 2). However, beta-carotene content (pg/cell) and its dry weight were higher in low $\mathrm{KNO}_{3}$ concentration (Table 2). Cell densities under high light intensity was lower, whereas the beta-carotene dry weight was higher than under the low light intensity although their difference were not significant $(\mathrm{t}=1.81, \mathrm{P}=0.36)$. Moreover, the beta-carotene content $\left(\mathrm{mg} \mathrm{l}^{-1}\right)$ in the way of multiple supplementing $\mathrm{KNO}_{3}$ was significantly lower than the way of one-time adding $\mathrm{KNO}_{3}$ (Figure 1 and Figure 2). Above results showed that the final biomass or beta-carotene content was mainly affected by the $\mathrm{KNO}_{3}$ concentration.

Carotenoids have been recognized to play essential roles in light harvesting for photosynthesis. Carotenoids could also prevent the injury to the cell from over high light intensity. Hence, light was considered an important factor to affect algae growth and beta-carotene accumulation. ${ }^{20}$ Light compensation point and saturated point of algae was $30 \mu \mathrm{mol} \mathrm{m} \mathrm{m}^{-2} \mathrm{~s}^{-1}$ and $600 \mu \mathrm{mol} \mathrm{m} \mathrm{m}^{-2} \mathrm{~s}^{-1}$ respectively and BenAmotz et al. found that increasing light intensity in this range was less effective for biomass accumulation but high effects for betacarotene accumulation. ${ }^{21}$ Results of this study were consistent with this view (Figure 1 and Figure 2) although the beta-carotene content ( $\mathrm{mg} \mathrm{L}^{-1}$ ) under high and low light intensity was not significant difference $(\mathrm{t}=2.23, \mathrm{P}=0.97)$.

Algae growing and beta-carotene accumulation obviously required different environment or nutrition levels. Generally, low stress intensity would promote the biomass accumulation but high stress intensity would improve betacarotene accumulation. Hence, two-phase cultivation was an effective way to improve the beta-carotene yields. ${ }^{2,8,19,22}$

The beta-carotene content (pg/cell) or dry weight was increased when the $\mathrm{KNO}_{3}$ concentration decreased (Table 2); however, the betacarotene content (mg L $\left.\mathrm{L}^{-1}\right)$ was improved when 
the $\mathrm{KNO}_{3}$ concentration increased (Figure 2). According to the methods of two-phase cultivation, the maximum biomass obtained at the low stress conditions, and then the biomass was quickly transferred to high stress intensity environment, such as low nitrate concentration, high light intensity, high salinity and high temperature etc. ${ }^{8,19}$ However, a fact that cell density was rapidly decreased when the biomass was transferred into the medium containing low $\mathrm{KNO}_{3}$ (Figure 2). This result further reflected that nitrate deprivation would significantly restrain algae growth or low nitrate would seriously affect the survival ratio of algae. $8,18,19,23$ Hence, high quantities of living cells in high nitrate concentration accumulated higher beta-carotene content although the accumulation of beta-carotene in each cell was lower.

It should be noticed that the total betacarotene yields by multiple supplementing nitrate was lower than by one-time giving nitrate. This could be related with the lack of enough nitrate limitation stress on each cell. Borowitzka et al. considered that wild $D$ salina can live better than the other organisms because of long-term adaptability to the environment, meanwhile, the stress from the environment such as high salinity, nutrition deprivation and high light intensity etc. could limit the cell division. Following the stress time extended, some Dunaliella cells conducted into the carotenogenesis condition and started to accumulate beta-carotene. $8,19,22,24,25$ During this period, the cell morphology was also changed, from ovoid to round or cell size increased, etc. Obviously, the more cells entered into the carotenogenesis conditions, the more accumulation of beta-carotene.

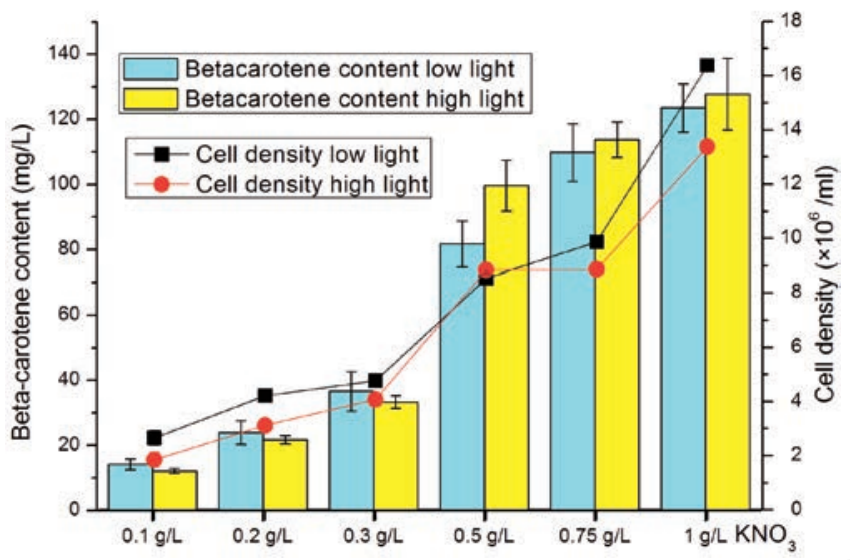

Figure 1. The cell density and beta-carotene content under different light intensity and $\mathrm{KNO}_{3}$ concentration. $\mathrm{KNO}_{3}$ was one-time added at the first day; all values were collected at $15^{\text {th }}$ cultivation day.

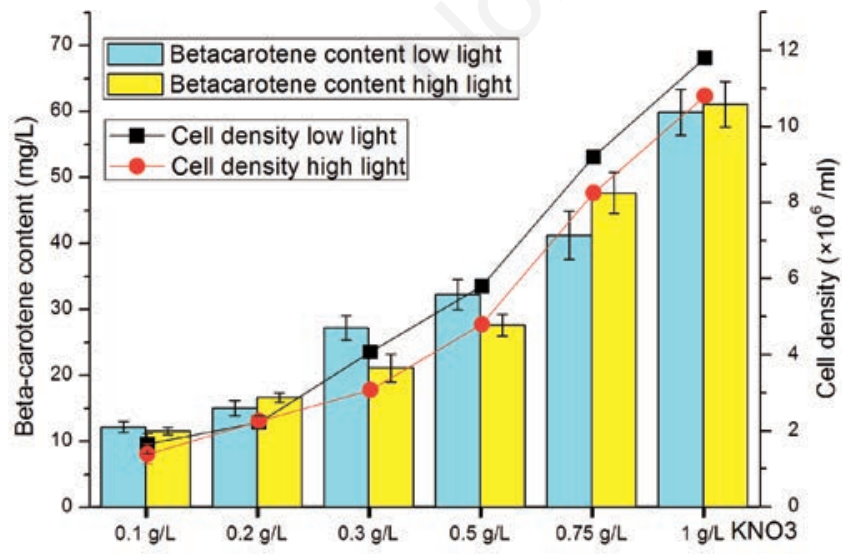

Figure 2. The cell density and beta-carotene content under different light intensity and $\mathrm{KNO}_{3}$ concentration. $\mathrm{KNO}_{3}$ was multiple supplemented every two days for maintaining the same concentration as the first day; all values were collected at $15^{\text {th }}$ cultivation day.

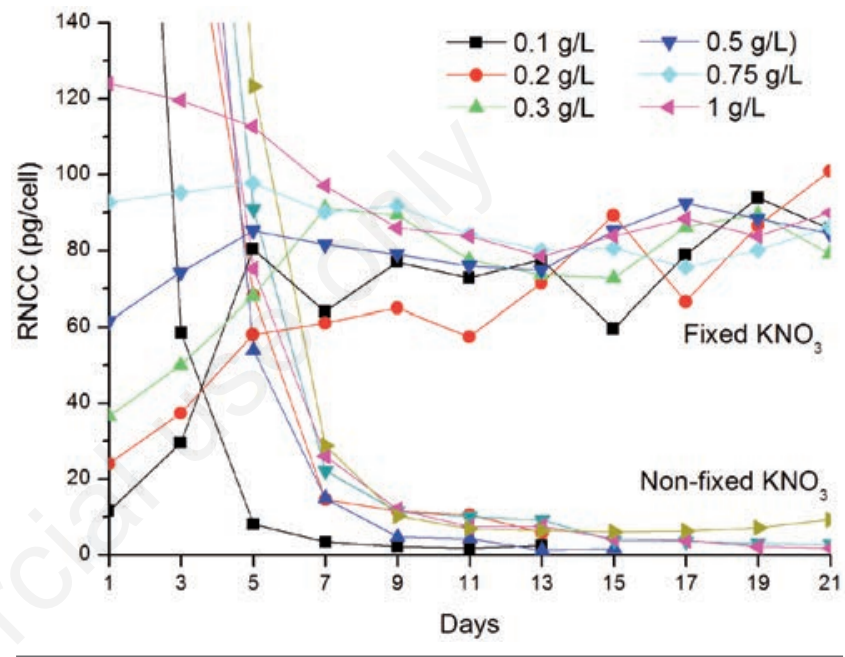

Figure 3. Remaining nitrate concentration in the culture of each cell under low light intensity. Fixed $\mathrm{KNO}_{3}$, multiple supplementing $\mathrm{KNO}_{3}$ to the culture every two days for maintaining the same concentration as the first day; Non-fixed $\mathrm{KNO}_{3}$, one-time adding $\mathrm{KNO}_{3}$ at the first day.

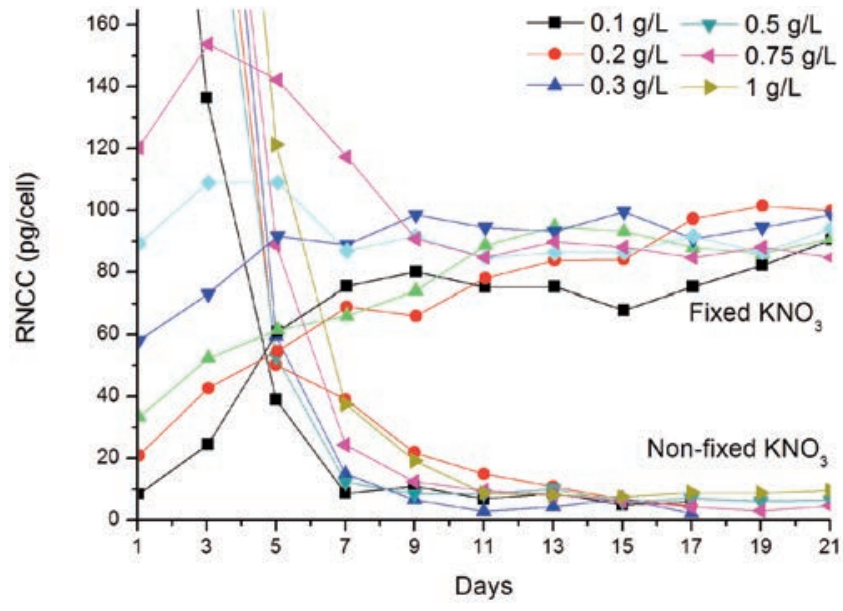

Figure 4. Remaining nitrate concentration in the culture of each cell under high light intensity. Fixed $\mathrm{KNO}_{3}$, multiple supplementing $\mathrm{KNO}_{3}$ to the culture every two days for maintaining the same concentration as the first day; Non-fixed $\mathrm{KNO}_{3}$, one-time adding $\mathrm{KNO}_{3}$ at the first day. 


\section{Remaining nitrate concentration in} the culture of each cell under low light intensity

Following the cultivation days extended, the cell was rapidly growing and $\mathrm{KNO}_{3}$ was quickly consumed that promote the RNCC rapidly decreased; meanwhile, RNCC of all cultures dramatically deceased and kept a stable and lowest level after 5-7 days (Figure 3). This result reflected that cell densities and the nutrition in the medium had formed a balance, which was based on the nutrition space of each cell. Long-term low RNCC was suitable to induce the algae cell into carotenogenesis conditions. According to the results shown in Figure 1 and Figure 2, beta-carotene content (mg L${ }^{-1}$ ) was higher in Non-fixed-KNO $\mathrm{K}_{3}$ group; it could be related with the low RNCC in this group. This result could be also explained by the algae adaptability to the environment.

Nitrate limitation is known to inhibit cell division, therefore the cells divide at a slow rate and produce more beta-carotene to protect the cells to prevent possible injury from radiation or maintain the photosynthesis. ${ }^{19,23}$ In addition, some algae died because of their low nitrate stress adaptability or natural senescence; hence, the way of one-time adding $\mathrm{KNO}_{3}$ provided a relative stable nitrate limitation environment and high started nitrate concentration remained more living cells in the late stage entering into carotenogenesis con- dition to accumulate more beta-carotene..$^{22}$ In the way of multiple supplementing $\mathrm{KNO}_{3}$, the RNCC was decreased, however their cell division was not significantly inhibited same as one-time adding $\mathrm{KNO}_{3}$; these new reproductive cells and the nitrate concentration formed a balance, but this balance could not promote more cells entering into carotenogenesis condition. Hence, beta-carotene content ( $\mathrm{mg} \mathrm{L}^{-1}$ ) in the way of multiple supplementing $\mathrm{KNO}_{3}$ was lower. Moreover, observing the algae cell could also reflect the relation between nitrate limitation and cell morphology variation.

Cells of Dunaliella are generally ovoid, 4-15 $\mu \mathrm{m}$ wide, and 6-25 $\mu \mathrm{m}$ long, but depending on stages of growth or development and environmental conditions. ${ }^{9}$ Cell of all cultures by onetime giving $\mathrm{KNO}_{3}$ showed an ovoid shape and the long diameter was $6-8 \mu \mathrm{m}$ before $10^{\text {th }}$ day; most cells changed to a round shape and diameters increased 1-3 $\mu \mathrm{m}$ during the second week and this tendency was significant when $\mathrm{KNO}_{3}$ arrange from $0.3-0.75 \mathrm{~g} \mathrm{l}^{-1}$. After three weeks, most of cells diameters increased 2-4 $\mu \mathrm{m}$ apart from cultures that the $\mathrm{KNO}_{3}$ was 0.1 , 0.2 and $1 \mathrm{~g} \mathrm{~L}^{-1}$. However, this variation was not significant in the culture by multiple supplementing $\mathrm{KNO}_{3}$ although a part of cells shape or size in the low $\mathrm{KNO}_{3}$ concentration was changed. Whatever conditions, this variation was closed related with RNCC. Obviously, low RNCC could be more suitable to induce more beta-carotene accumulation.

\section{Remaining nitrate concentration in} the culture of each cell under high light intensity

The variation of RNCC under high light intensity was similar as previous results. RNCC of all cultures dramatically decreased and kept a stable and lowest level after 5-7 days (Figure 4). The value of RNCC was calculated based on the nitrate concentration and cell density, in addition, effects of light intensity on cell growth was not significant as shown in Figure land Figure 2; hence, the variation tendency of RNCC between high and low light intensity was not big difference especially in the way of multiple supplementing $\mathrm{KNO}_{3}$. However, their values still had a few differences. In the way of one-time adding $\mathrm{KNO}_{3}$, RNCC of all cultures under high light intensity dramatically decreased below $20 \mathrm{pg} /$ cell after one week and $10 \mathrm{pg} / \mathrm{cell}$ after two weeks; correspondingly, RNCC of all cultures under low light intensity was almost below $10 \mathrm{pg} / \mathrm{cell}$ after one week. This result showed that high light intensity could improve the nitrate limitation to start to accumulate beta-carotene early. It was related with the proposed function of beta-carotene accumulation in Dunaliella as a protection of the cell against injury by high intensity irradiation. The higher the intensity to which the algae are exposed, the higher is their beta-carotene. ${ }^{21}$

Table 1. Cell growth and beta-carotene content under different $\mathrm{KNO}_{3}$ concentration and light intensity.

\begin{tabular}{|c|c|c|c|c|c|c|c|c|}
\hline \multirow[t]{2}{*}{$\begin{array}{l}\mathrm{KNO}_{3} \\
\left(\mathrm{~g} \mathrm{~L}^{-1}\right)\end{array}$} & \multicolumn{2}{|c|}{$\begin{array}{l}\text { Specific growth } \\
\text { rate ( } 1 \text { ) }\end{array}$} & \multicolumn{2}{|c|}{ Biomass (g/L) } & \multicolumn{2}{|c|}{$\begin{array}{l}\text { Beta-carotene } \\
\text { dry weight }(\mathrm{mg} / \mathrm{g})\end{array}$} & \multicolumn{2}{|c|}{$\begin{array}{c}\text { Beta-carotene } \\
\text { content per cell (pg/cell) }\end{array}$} \\
\hline & L-light & H-light & L-light & H-light & L-light & H-light & L-light & H-light \\
\hline 0.1 & $0.60 \pm 0.03^{\mathrm{ab}}$ & $0.40 \pm 0.03^{\mathrm{a}}$ & $0.29 \pm 0.03^{\mathrm{a}}$ & $0.21 \pm 0.04^{\mathrm{a}}$ & $48.5 \pm 5.8^{\mathrm{a}}$ & $56.8 \pm 3.7^{\mathrm{a}}$ & $5.4 \pm 0.9^{\mathrm{a}}$ & $6.6 \pm 0.7^{\mathrm{a}}$ \\
\hline 0.2 & $0.60 \pm 0.04^{a}$ & $0.61 \pm 0.04^{\mathrm{b}}$ & $0.50 \pm 0.03^{\mathrm{b}}$ & $0.38 \pm 0.03^{b}$ & $48.4 \pm 7.3 \mathrm{a}$ & $57.2 \pm 3.3^{\mathrm{a}}$ & $5.5 \pm 0.9^{a}$ & $7.0 \pm 0.4^{\mathrm{a}}$ \\
\hline 0.3 & $0.68 \pm 0.06^{\mathrm{b}}$ & $0.63 \pm 0.03^{\mathrm{bc}}$ & $0.65 \pm 0.03^{c}$ & $0.58 \pm 0.04^{c}$ & $56.7 \pm 9.3^{\mathrm{ab}}$ & $57.3 \pm 3.3^{\mathrm{a}}$ & $7.7 \pm 0.8^{b}$ & $8.2 \pm 0.3^{b}$ \\
\hline 0.5 & $0.68 \pm 0.03^{b}$ & $0.64 \pm 0.04^{b c}$ & $1.26 \pm 0.09 \mathrm{~d}$ & $1.39 \pm 0.03 \mathrm{~d}$ & $64.8 \pm 4.0^{\mathrm{bc}}$ & $71.5 \pm 5.6 \mathrm{~b}$ & $9.6 \pm 0.5^{c}$ & $11.4 \pm 0.5^{\mathrm{d}}$ \\
\hline 0.75 & $0.62 \pm 0.03^{\mathrm{ab}}$ & $0.73 \pm 0.03^{\mathrm{d}}$ & $1.53 \pm 0.04 \mathrm{e}$ & $1.48 \pm 0.04 \mathrm{e}$ & $71.6 \pm 5.8^{c}$ & $76.7 \pm 3.7^{\mathrm{b}}$ & $11.1 \pm 0.8^{\mathrm{d}}$ & $12.8 \pm 0.6^{\mathrm{e}}$ \\
\hline 1 & $0.63 \pm 0.04^{\mathrm{a}}$ & $0.68 \pm 0.03^{\mathrm{cd}}$ & $2.25 \pm 0.07^{\mathrm{f}}$ & $2.17 \pm 0.04^{\mathrm{f}}$ & $54.9 \pm 3.3^{\mathrm{a}}$ & $58.6 \pm 5.1^{\mathrm{a}}$ & $7.6 \pm 0.6 \mathrm{~b}$ & $9.6 \pm 0.7 \mathrm{c}$ \\
\hline
\end{tabular}

$\mathrm{KNO}_{3}$ was one-time added and all data were collected at $15^{\text {th }}$ day; L-light, low light intensity; H-light, high light intensity; values having a common letter are not significantly difference at $\mathrm{P}=5 \%$.

Table 2. Cell growth and beta-carotene content under different light intensity and $\mathrm{KNO}_{3}$ concentration.

\begin{tabular}{|c|c|c|c|c|c|c|c|c|}
\hline \multirow[t]{2}{*}{$\begin{array}{l}\mathrm{KNO}_{3} \\
\left(\mathrm{~g} \mathrm{~L}^{-1}\right)\end{array}$} & \multicolumn{2}{|c|}{$\begin{array}{l}\text { Relative growth } \\
\text { rate }(\mu)\end{array}$} & \multicolumn{2}{|c|}{ Biomass (g/L) } & \multicolumn{2}{|c|}{$\begin{array}{l}\text { Beta-carotene } \\
\text { dry weight }(\mathrm{mg} / \mathrm{g})\end{array}$} & \multicolumn{2}{|c|}{$\begin{array}{l}\text { Beta-carotene } \\
\text { content per cell (pg/cell) }\end{array}$} \\
\hline & L-light & H-light & L-light & H-light & L-light & H-light & L-light & H-light \\
\hline 0.1 & -0.11 & -0.13 & $0.17 \pm 0.02^{\mathrm{a}}$ & $0.15 \pm 0.02^{\mathrm{a}}$ & $73.3 \pm 4.8^{\mathrm{d}}$ & $79.2 \pm 3.5^{\mathrm{d}}$ & $7.34 \pm 0.46^{\mathrm{c}}$ & $8.36 \pm 0.44^{c}$ \\
\hline 0.2 & -0.09 & -0.09 & $0.24 \pm 0.03^{a}$ & $0.26 \pm 0.03^{a}$ & $63.1 \pm 4.8^{c}$ & $64.1 \pm 2.7^{c}$ & $6.75 \pm 0.53^{b}$ & $7.25 \pm 0.63^{b}$ \\
\hline 0.3 & -0.05 & -0.07 & $0.51 \pm 0.04^{b}$ & $0.47 \pm 0.12^{b}$ & $53.2 \pm 3.6^{\mathrm{b}}$ & $51.2 \pm 4.5^{\mathrm{b}}$ & $6.68 \pm 0.44^{b}$ & $6.88 \pm 0.29^{b}$ \\
\hline 0.5 & -0.02 & -0.04 & $0.80 \pm 0.03^{\mathrm{c}}$ & $0.65 \pm 0.06^{c}$ & $40.5 \pm 2.9^{\mathrm{a}}$ & $43.7 \pm 2.5^{\mathrm{a}}$ & $5.56 \pm 0.18^{\mathrm{a}}$ & $5.76 \pm 0.2^{\mathrm{a}}$ \\
\hline 0.75 & 0.01 & 0.002 & $1.05 \pm 0.14^{\mathrm{d}}$ & $1.06 \pm 0.15^{\mathrm{d}}$ & $39.6 \pm 3.5^{\mathrm{a}}$ & $46.7 \pm 2.9^{a b}$ & $5.73 \pm 0.29^{a}$ & $5.78 \pm 0.31^{\mathrm{a}}$ \\
\hline 1 & 0.03 & 0.02 & $1.38 \pm 0.13^{\mathrm{e}}$ & $1.37 \pm 0.02^{\mathrm{e}}$ & $43.5 \pm 2.5^{\mathrm{a}}$ & $44.7 \pm 2.1^{\mathrm{a}}$ & $5.54 \pm 0.19^{a}$ & $5.64 \pm 0.3^{a}$ \\
\hline
\end{tabular}

$\mathrm{KNO}_{3}$ was multiple supplemented and all data were collected at $15^{\text {th }}$ day; Relative growth rate (RGR), the growth under the constant $\mathrm{KNO}_{3}$ concentration did not show a sigmoid curve, hence, RGR used here to replace the specific growth rate, also, the data analysis here was omitted; L-light, low light intensity; H-light, high light intensity; values having a common letter are not significantly difference at $\mathrm{P}=5 \%$. 
Results of this study showed that the final beta-carotene content was related with the started nitrate concentration. Therefore, the higher started nitrate concentration for this D.salina strain, the higher beta-carotene yields obtained. However, it was not practical for the commercial algae cultivation. High input of nitrate required more costs and long cultivation time to produce beta-carotene. As results had shown in Figure land Figure 2, the beta-carotene content did not show a significant difference between 0.75 and $1 \mathrm{~g}^{-1}$ at $15^{\text {th }}$ day, therefore, 0.5 or $0.75 \mathrm{~g} \mathrm{~L}^{-1}$ would be suitable for this strain to produce beta-carotene. In addition, improving light intensity could improve the beta-carotene accumulation although the light intensity that over light compensation point (about $600 \mu \mathrm{mol} \mathrm{m} \mathrm{m}^{-2} \mathrm{~s}^{-1}$ ) was not test in this study because of the experimental conditions limited.

\section{Conclusions}

The final beta-carotene content related with the started nitrate concentration. High started $\mathrm{KNO}_{3}$ concentration could promote high cell quantities and beta-carotene content. Its essence was that high started nitrate concentration could remain more cells in the late stage entering into the carotenogenesis condition to accumulate more beta-carotene. Nitrate limitation could be reflected by the value of RNCC. Low RNCC (below approx. 20 pg/cell) was an advantage for beta-carotene accumulation and the low RNCC level was irrelevant with started $\mathrm{KNO}_{3}$ concentration. This means whatever low or high started $\mathrm{KNO}_{3}$ concentration, it could be consumed following the algae growing and culture time extended and finally the RNCC would tend to the same level. However, the started nitrate concentration could not be too high or too low otherwise the algae required long time to accumulate betacarotene or the beta-carotene yields was lower because of low biomass. High light intensity could limit the growth especially in low $\mathrm{KNO}_{3}$ concentration but improve the beta-carotene accumulation and RNCC. Results of this study advised that increasing the biomass and as early to strengthen the stress on each cell was important to improve the beta-carotene yield.

\section{References}

1. Shen YC, Chng LM, Wang YC, et al.
Production of all trans-beta-carotene by using impinging flow of supercritical carbon dioxide anti-solvent pulverization. $\mathrm{J}$ Chromatogr 2012;1270:1-8.

2. Prieto A, Pedro Cañavate J, GarcíaGonzález M. Assessment of carotenoid production by dunaliella salina in different culture systems and operation regimes. J Biotechnol 2011;151:180-5.

3. Choudhari S, Singhal R. Media optimization for the production of $\beta$-carotene by blakeslea trispora: a statistical approach. Bioresour Technol 2008;99:722-30.

4. Hosseini Tafreshi A, Shariati M. Dunaliella biotechnology: methods and applications. J Appl Microbiol 2009;107:1435.

5. Lam MK, Lee KT. Scale-up and commercialization of algal cultivation and biofuel production. In: Pandey A, Lee DJ, Chisti Y, Soccol CR, eds. Biofuels from algae. Amsterdam: Elsevier; 2014. pp 261-286.

6. Farhat $\mathrm{N}$, Rabhi $\mathrm{M}$, Falleh $\mathrm{H}$, et al. Optimization of salt conditions for a higher carotenoid production in dunaliella salina (chlorophyceae)1. J Phycol 2011;47: 1072-7.

7. Lamers PP, Janssen M, De Vos RCH, et al. Exploring and exploiting carotenoid accumulation in dunaliella salina for cell-factory applications. Trends Biotechnol 2008;26:631-8.

8. Ben-Amotz A, Avron M. The biotechnology of cultivating the halotolerant algadunaliella. Trends Biotechnol 1990;8:121-6.

9. Sathasivam R, Juntawong N. Modified medium for enhanced growth of dunaliella strains. Int J Curr Sci 2013;5:67-73.

10. Ben-Amotz A. New mode of dunaliella biotechnology: two-phase growth for $\beta$ carotene production. J Appl Phycol 1995;7:65-8.

11. Uriarte I, Farías A, Hawkins AJS, Bayne BL. Cell characteristics and biochemical composition ofdunaliella primolecta butcher conditioned at different concentrations of dissolved nitrogen. J Appl Phycol 1993;5:447-53.

12. Marín N, Morales F, Lodeiros C, Tamigneaux E. Effect of nitrate concentration on growth and pigment synthesis of dunaliella salina cultivated under low illumination and preadapted to different salinities. J Appl Phycol 1998;10:405-11.

13. Borowitzka LJ, Borowitzka MA. B-carotene (provitamin a) production with algae. In: Vandamme E, ed. Biotechnology of vitamins, pigments and growth factors.
Elsevier applied biotechnology series: Springer Netherlands; 1989. p. 15-26.

14. Cowan AK, Rose PD. Abscisic acid metabolism in salt-stressed cells of dunaliella salina: Possible interrelationship with $\beta$ carotene accumulation. Plant Physiol. 1991;97:798-803.

15. Mogedas B, Casal C, Forján E, Vílchez C. Bcarotene production enhancement by uv-a radiation in dunaliella bardawil cultivated in laboratory reactors. J Biosci Bioeng. 2009;108:47-51.

16. Masojídek J, Torzillo G, Koblížek M. Photosynthesis in microalgae. Handbook of microalgal culture. Hoboken: John Wiley \& Sons, Ltd; 2013. pp 21-36.

17. Cuttriss AJ, Cazzonelli CI, Wurtzel ET, Pogson BJ. Carotenoids. In: Fabrice R, Roland D, eds. Adv Bot Res 2011;58:1-36.

18. Markou G, Nerantzis E. Microalgae for high-value compounds and biofuels production: a review with focus on cultivation under stress conditions. Biotechnol Adv 2013;31:1532-42.

19. Ben-Amotz A. Effect of irradiance and nutrient deficiency on the chemical composition of dunaliella bardawil ben-amotz and avron (volvocales, chlorophyta). J Plant Physiol 1987;131:479-87.

20. Stamatakis K, Tsimilli-Michael M, Papageorgiou GC. On the question of the light-harvesting role of $\beta$-carotene in photosystem ii and photosystem i core complexes. Plant Physiol Biochem 2014;81:121-7.

21. Ben-Amotz A, Avron M. On the factors which determine massive $\beta$-carotene accumulation in the halotolerant alga dunaliella bardawil. Plant Physiol 1983;72:593-7.

22. Ye ZW, Jiang JG, Wu GH. Biosynthesis and regulation of carotenoids in dunaliella: progresses and prospects. Biotechnol Adv 2008;26:352-60.

23. Phadwal K, Singh PK. Effect of nutrient depletion on $\beta$-carotene and glycerol accumulation in two strains of dunaliella sp. Bioresour Technol 2003;90:55-8.

24. Borowitzka, A. M. Microalgae as a source of pharmaceuticals and other biologically active compounds. J Appl Phycol 1995;7:315.

25. Jiang JG, Zhu YH. Preliminary and comparative studies on the cultivations of dunaliella salina between outdoors and in the photobioreactor. J Food Process Eng 2010;33:104-14. 